\title{
Evaluation of the Relationship between Burnout and Psychological Symptoms among Staff Working with Individuals with Disabilities and Elderly
}

\section{Engelli ve Yaşlı Bakım Personelinin Tükenmişlik ve Ruhsal Belirti Düzeyleri Arasındaki İlişkinin İncelenmesi}

\author{
Meltem Oral $^{1}$, Nurgül Karakurt ${ }^{2}$
}

\begin{abstract}
:
Burnout syndrome can adversely affect individuals who work in professions that are in close contact with people, and this can contribute to deterioration in their mental health. The purpose of this research was to investigate the association between burnout levels and the psychological symptoms of disabled and elderly workers in the centers of disability and rehabilitation in Erzurum, Turkey. A total of 200 participants, 83 women, and 40 men participated in the study. Maslach Burnout Scale and Brief Symptom Inventory were administered to participants. The findings of the study indicated that the staff's level of emotional exhaustion and depersonalization was moderate and the level of personal accomplishment was high. Obsessive-compulsive disorder, paranoid thought, and somatization were found to be among the most common psychological symptoms among the participants. The current study also has shown that as the emotional exhaustion and depersonalization levels of the staff increased, so did their psychological symptoms, and as their personal achievement levels increased, their psychological symptoms decreased. Burnout appears to implicate mental health status of personnel working with individuals with disabilities and the elderly in care institutions.
\end{abstract}

Keywords: Burnout, Mental Health, Healthcare Team

\footnotetext{
${ }^{1}$ Assist. Prof., Ataturk University, Vocational College of Health Services, Erzurum-Turkey, Orcid Id: https://orcid.org/ 00000002-7082-9186

${ }^{2}$ Assist. Prof., Erzurum Technical University Faculty of Health Sciences, Department of Nursing, Erzurum-Turkey, Orcid Id: https://orcid.org/ 0000-0001-7598-6554
}

Address of Correspondence/Yazş̧ma Adresi: Ataturk University, Vocational College of Health Services, Erzurum-Turkey, E-mail: meltem_oral@yahoo.com

Date of Received/Geliş Tarihi: 24.02.2021, Date of Revision/Düzeltme Tarihi: 12.05.2021, Date of Acceptance/Kabul Tarihi: 31.05.2021, Date of Online Publication/Çevirimiçi Yayın Tarihi: 01.06.2021

Citing/Referans Gösterimi: Oral, M., Karakurt, N. (2021). Evaluation of the Relationship between Burnout and Psychological Symptoms among Staff Working with Individuals with Disabilities and Elderly, Cyprus Turkish Journal of Psychiatry \& Psychology, 3(2): 123-131.

(C) 2021 The Author(s). Published by Cyprus Mental Health Institute / Cyprus Turkish Journal of Psychiatry and Psychology (www.ktppder gisi.com). This article is an open access article distributed under the terms and conditions of the Creative Commons Attribution 4.0 license which permits use, sharing, adaptation, distribution and reproduction in any medium or format, provided the original work is properly cited and is not used for commercial purposes. https://creativecommons.org/licenses/by-nc-sa/4.0/ 


\section{Öz:}

Tükenmişlik sendromu özellikle sağlı alanında çalışan bireyleri olumsuz olarak etkileyebilmekte ve bu durum ruh sağlığında bozulmalara yol açabilmektedir. Bu çalışmanın amacı, Erzurum il merkezinde bulunan engelli bakım ve rehabilitasyon merkezlerinde engelli ve yaşlı bakım elemanı olarak çalışan personelin tükenmişlik ile ruhsal belirti düzeyleri arasındaki ilişkiyi incelemektir. Çalışmaya bakım kurumlarında çalışan 83'ü kadın, 40'1 erkek toplam 200 engelli ve yaşlı bakım personeli katılmıştır. Çalışmada Maslach Tükenmişlik Ölçeği ve Kısa Semptom Envanteri kullanılmıştır. Çalışmanın bulguları katılımcıların orta düzeyde duygusal tükenme ve duyarsızlaşma ve yüksek düzeyde kişisel başarı yaşadıklarını göstermektedir. Katılımcılarda en sık görülen ruhsal belirtiler arasında obsesif kompulsif bozukluk, paranoid düşünce ve somatizasyon olduğu saptanmıştır. Ayrıca bu çalışma engelli ve yaşlı bakım personelinin duygusal tükenmişlik ve duyarsızlaşma düzeyleri arttıkça ruhsal belirti düzeylerinin arttı̆ğını ve kişisel başarı düzeyleri arttıkça ruhsal belirti düzeylerinin azaldığını göstermektedir. Sonuç olarak bakım kurumlarında çalışan engelli ve yaşlı personelinin tükenmişlik duygularıyla ruhsal belirti düzeyleri arasında yüksek düzeyde bir ilişki olduğu tespit edilmiştir.

Anahtar Kelimeler: Tükenmişlik, Ruh Sağlığı, Hasta Bakım Ekibi

\section{Giriş}

Bireylerin yaşam süresinin uzamasına katkı sağlayan sağlık alanındaki gelişmeler sonucunda hem dünyada hem de Türkiye'de engelli ve yaşlıların sayısının gün geçtikçe arttığı gözlemlenmektedir. Ortalama ömrün uzamasının yanı sıra, kadınların iş gücüne katılım oranının artmasıyla geleneksel aileden çekirdek aileye geçilmesi ve kronik bazı sağlık sorunlarındaki artış bakıma ihtiyaç duyan kişilerin sayısında da artmaya yol açmaktadır (Danış ve Genç, 2011). Ülkemizde engelli ve yaşlıların artan gereksinimlerini karşılamak için T.C. Aile ve Sosyal Hizmetler Bakanlığı, belediyeler, özel kurumlar ve vakıflar bakım personelleri aracilığıyla gerekli bakım hizmetlerini sağlamaktadır. T.C. Aile ve Sosyal Hizmetler Bakanlığı, Engelli ve Yaşlı Hizmetleri Genel Müdürlüğü ve Mesleki Yeterlilik Kurumu (MYK), engelli ve yaşlı bakım personeline yönelik mesleki tanımlama ve ulusal standartları Resmi Gazetede 25 Ekim 2016 tarihinde yayımlayarak tebliğ etmiştir. Bu tanıma göre engelli ve yaşlı bakım elemanı, "iş sağlığı ve güvenliği ile çevre koruma ile ilgili alınan önlemleri uygulayarak, mesleği ile ilgili kalite gereklilikleri çerçevesinde; bakım öncesi ön hazırlık yapan, hizmet alan bireyin öz bakımını uygulayan, yaşam alanını düzenleyen, yeterli ve dengeli beslenmesini sağlayan, hareket etme yeteneğini kazandıran, ilaç harici tıbbi bakımını sağlık personeli denetiminde yapan, aktif yaşama katılımını sağlayan, tedavi sürecinde sağlık personelini destekleyen ve mesleki gelişim faaliyetlerine katılan nitelikli kişi” şeklinde tanımlanmıştır (MYK, 2016).

Stresli çalışma ortamlarına maruz kalan engelli ve yaşlı bakım personeli hizmet verdikleri kesimin sorunları ve ihtiyaçlarıyla sürekli bir şekilde ilgilendiklerinden dolayı fiziksel, ruhsal ve sosyal bakımdan olumsuz olarak etkilenebilmekte ve yorgunluk, stres düzeyinde artış, depresif duygudurum, kayg1 ve tükenmişlik, gibi sorunlarla karşı karşıya kalabilmektedirler (Hendekçi ve Gök Uğur, 2019; Sağlam, 2017). Tükenmişlik sendromu özellikle sağlık alanında çalışan personeli etkilemekte (Aslan ve Erbay, 2017) ve bu durum da meslek elemanlarının hizmet sundukları kişilere verdikleri ilgi ve özeni baltalamaktadır.

\section{Tükenmișlik Kavramı}

Tükenmişlik kavramı 1970'li yıllarda ilk defa Freudenberger tarafindan yazılan bir makale ile alanyazına girmiştir (Freudenberger, 1974). Freudenberger'in tanımına göre tükenmişlik, "başarısız olma, yıpranma, aşırı yüklenme sonucu güç ve enerji kaybı veya tatmin edilemeyen istekler sonucu bireyin iç kaynaklarında tükenme durumudur. (Freudenberger, 1974). Tükenmişliğin en kabul gören tanımını 1981 yılında Maslach ve Jackson yapmıştır. Maslach ve Jackson'a göre tükenmişlik “insanlarla çalışmayı gerektiren işlerde görev yapanlarda görülen, duygusal tükenme ve olumsuz düşüncelere kapılma, mesleğinin anlam ve hedefinden koparak hizmet verilen insanlarla ilgilenilmemesi şeklinde gelişen bir psikolojik sendrom"dur (Maslach ve Jackson, 1981). Maslach ve Leiter (2016) daha sonra "tükenmişliği işyerinde kişilerarası stresörlere uzun süre maruz kalma sonucunda ortaya çıkan psikolojik bir sendrom" olarak tanımlamışlardır. Maslach ve Jackson (1981) tükenmişliğin belirtilerini bedensel, ruhsal ve davranışsal olmak üzere üç kategori altında toplamışlardır. Tükenmişliğin fiziksel belirtileri arasında yorgunluk ve enerji eksikliği, kalp çarpıntısı, gastrointestinal şikâyetler, uyku sorunları ve kronik ağrılar yer almaktadır. Tükenmişliğin ruhsal belirtileri arasında ümitsizlik hissi, özgüven eksikliği, değersizlik hisleri, kaygı ve huzursuzluk, ani öfkelenme bulunmaktadır. Tükenmişliğin davranışsal belirtileri arasında ise ani tepkiler verme, alınganlık, sabırsızlık, işleri erteleme, kendini savunma, başkalarını suçlama gibi bazı belirtiler yer almaktadır.

Tükenmişliği konu alan araştırmalara tükenmişliği üç boyutta kavramsallaştıran Maslach ve Jackson'ın çalışmaları yön vermektedir. $\mathrm{Bu}$ boyutlar sırasıyla duygusal tükenme, duyarsızlaşma ve kişisel başarı boyutudur. Duygusal tükenmenin bireyin işinde vermekte olduğu hizmetle ilgili duygusal kaynaklarının tükenmesi ve bunun sonucunda işindeki sorumlulukları yerine getiremediğini düşünerek işe gitme zorunluluğunun aşırı kayg1 durumu oluşturması durumu olduğu belirtilmektedir (Bilgin, Emhan ve Bez, 2011: 215). Bu boyutun tükenmişlik sendromunun ilk ve en önemli özelliği olduğu ve esas olarak kişilerarası ilişkilerdeki aşırı yük ve kişisel çatışmalar nedeniyle ortaya çıktığ 
düşünülmektedir. Tükenmişliğin ikinci aşaması ise duyarsızlaşmadır. İş hayatında duygusal tükenme yaşayan birey, hizmet verdiği ve çalıştığı kişilere ve ayrıca yöneticilere karşı duyarsızlaşmaya başlamaktadır. Duyarsızlaşma boyutu bireylerarası iletişimin önemini ortaya koymaktadır. $\mathrm{Bu}$ aşamada birey, çalışma arkadaşları ve hizmet verdiği kişilerle arasına bilinçli olarak bir set çekerek, iletişime geçmeme, karşısındaki bireyin de kendisiyle iletişime geçmesini engelleme, ilgilenmeme, samimiyetsiz olma gibi davranışlar sergileyebilmektedir. (Sağlam, 2017). Tükenmişliğin son boyutunda duygusal tükenme yaşayı duyarsızlaşan birey kişisel başarı eksikliği yaşayabilmektedir. Kişisel başarı eksikliği, bireyin görevli olduğu işle alakalı olarak kendisi hakkında olumsuz değerlendirmeler yapmasi; diğer bir deyişle kendisini başarısız hissetmesi anlamına gelmektedir (Oğuzberk ve Aydın, 2009). Bu alanda yapılan araştırmalar tükenmişliğin işyerinde düşük performansla ilişkili olduğunu (Ruotsalainen vd., 2015) ve genellikle işe devamsızlık ve işten ayrılma gibi bireyde sosyal izolasyona yol açtığını göstermektedir (Kim ve Kao, 2014). Maslach'in tükenmişlik modelinde duygusal tükenme alt boyutu tükenmenin bireysel stres durumunu, duyarsızlaşma alt boyutu tükenmenin kişilerarası ilişki durumunu, düşük kişisel başarı ise kişisel yeterlilik ve başarı duyguları olarak tanımlanmaktadır (Çoban-Kaymak, 2018). Sağlık bakım hizmetleri alanında çalışan kişilerin olumsuz çalışma koşulları, iş devamsızlığı (Aagestad vd., 2016), yüksek düzeyde personel değișim oranı (Mazurenko vd., 2015) ve tükenmişlik (Gray-Stanley ve Muramatsu, 2011; Innstrand ve diğerleri, 2004; Borritz ve diğerleri, 2005) olmak üzere bir dizi kötü sonuçla ilişkilendirilmiştir.

Tükenmişlik bireyin insan yaşamının her alanında sorunlar yaratabilmektedir. Kişilerarası, kişisel ve aile ilişkileri üzerinde olumsuz bir etkisi olabilmekte ve hayata karşı genel bir olumsuz tutuma yol açabilmektedir (Papathanasiou, 2015). Bu yönüyle tükenmişliğin bazı ruhsal bozukluklarla ortak özelliklere sahip olması beklenmektedir.

\section{Engelli ve Yaşıı Bakım Personellerinde Tükenmişlik ve Ruhsal Belirti Düzeyleri Arasındaki İlişki}

Farklı nedenlerle yaşadıkları stresle başa çıkma ve engelli ve yaşlilara uygun yaklaşımda bulunmada yetersiz kalabilen engelli ve yaşlı bakım personelinin iş yükünün çokluğundan dolayı ruhsal belirtiler ortaya çıkarma riski de yüksek olabilmektedir. Milner, King ve Kavanagh (2019), sağlık ve bakım hizmetleri alanında çalışan kişilerin ruh sağlığını değerlendirdiği çalışmada bakım personelinin, doktorlar ve hemşirelere göre psikososyal iş stresine maruz kalma olasılıklarının daha yüksek olduğunu göstermektedir. Ayrıca, bu çalışma bakım personelinin diğer çalışanlara göre ruh sağlığının daha bozuk olduğunu ve psikososyal iş stresine maruz kaldıklarında ruhsal sağlıklarında düşüşlere daha açık olduklarını da göstermektedir. Kim ve ark.(2018) yaptıkları çalışmada sağlık bakım hizmetinde çalışanlarda duygudurum bozuklukları, anksiyete bozuklukları, uyku bozuklukları ve tüm psikiyatrik bozuklukların yaygınlığının diğer alanlarda çalışanlardan daha yüksek olduğunu belirtmişlerdir.

Ahola ve ark. 2005 tükenmişlik ile depresyon arasında yüksek düzeyde pozitif bir ilişki olduğunu bildirmektedir. Peterson ve ark. (2008), yaptıkları çalışmada tükenmişliğin depresyon ve anksiyete ile ilişkili olduğunu açığa çıkarmaktadır. Koutsimani, Montgamery ve Georganta (2019)'nın depresyon ve anksiyete ile tükenmişlik arasındaki ilişkiyi inceleyen çalışmaları gözden geçirdikleri meta-analiz çalışmasının sonucunda tükenmişlik ile depresyon ve anksiyete arasında bir ilişki olduğunu ve bu kavramların birbirleriyle bağlantılı olmalarına rağmen aynı yapılar olmadığını göstermektedir. Yunusoğlu (2018), sağlık kurumlarında çalışan personelde tükenmişlik düzeyinin depresyon üzerindeki etkisine baktığı çalışmada tükenmişlik sendromu ve çalışanların stresli olmalarının depresyon düzeylerini artırdığ 1 sonucuna ulaşmıştır. Korkut (2017), bakım elemanlarının tükenmişlik düzeyleri ile psikolojik belirtiler arasındaki ilişkiye baktığı çalışmada bakım personelinin tükenmişlik düzeyi arttıkça psikolojik belirtilerinin de arttığını belirtmektedir. Bilgin, Emhan ve Bez (2011) yaptıkları çalışmada depresyon ile tükenmişlik arasında pozitif yönde bir ilişkinin olduğunu göstermektedir. Bundan dolayı T.C. Aile ve Sosyal Hizmetler Bakanlığı Erzurum İl Müdürlügü’ne bağlı kurumlarda bakım hizmet kalitesinin artırılması için engelli ve yaşlı bakım personelinin tükenmişlik düzeyleri ile ruhsal sağlık durumlarının araştırılmasına gereksinim duyulmuştur.

\section{Gereç ve Yöntem}

\section{Araştırmanın Amacı}

Araştırma; AÇHSB Erzurum İl Müdürlüğü'ne bağlı bakım kurumlarında çalışan engelli ve yaşlı bakım personelinde tükenmişlik ile ruhsal belirti düzeyleri arasındaki ilişkinin incelenmesi amaçlı tanımlayıcı bir çalışma olarak planlanmıştır. Çalışmada genel tarama modellerinden biri olan ilişkisel tarama modeli kullanılmıştır. Genel tarama modeli çok sayıda elemanı olan bir evrende, bu evrenle alakalı genel bir kanıya sahip olabilmek için evrenin bütünü ya da evrenden alınan bir grup üzerinde yapılan tarama şeklidir (Karasar, 2011).

Araştırma sonucunda aşağıda yer alan alt amaçlara ulaşmak hedeflenmiştir:

- Katılımcıların sosyo-demografik özellikleri nedir?

- Katılımcıların tükenmişlik düzeyleri nedir?

- Katılımciların ruhsal belirti düzeyleri nedir?

- Katılımcıların tükenmişlik ile ruhsal belirti düzeyleri ile arasında bir ilişki bulunmakta midir?

\section{Araştırmanın Hipotezleri}

- $\quad \mathbf{H}_{\mathbf{0}}=$ Engelli ve yaşlı bakım elemanlarının tükenmişlik ve ruhsal belirti düzeyleri arasında bir ilişki yoktur.

- $\quad \mathbf{H}_{\mathbf{1}}=$ Engelli ve yaşlı bakım elemanlarının tükenmişlik ve ruhsal belirti düzeyleri arasında güçlü bir ilişki vardır.

\section{Araştırmanın Evreni ve Örneklemi}

Araştırmanın evrenini T.C. Aile ve Sosyal Hizmetler Bakanlığı Erzurum İl Müdürlüğü'ne bağlı bakım kurumlarında çalışan engelli ve yaşlı bakım personeli $(\mathrm{N}=200)$ oluşturmaktadır. Araştırmada olasılıklı olmayan 
örnekleme yöntemlerinden kolayda örnekleme yöntemi kullanılmıştır. T.C. Aile ve Sosyal Hizmetler Bakanlığı Erzurum İl Müdürlüğü'ne bağlı bakım kurumlarında çalışan bakım personeline ulaşılarak çalışmaya katılmayı kabul eden tüm bakım personeline ulaşılması hedeflenmiştir. Çalışmaya katılmayı kabul eden 123 bakım personeli araştırmanın örneklemini oluşturmuştur. Araştırma gerçekleştirilmeden önce Atatürk Üniversitesi Tıp Fakültesi Klinik Araştırmalar Etik Kurulu'ndan onay alınmıştır.

\section{Veri Toplama Araçları}

Çalışmada veri toplama araçları olarak hazırlanan 'Sosyodemografik Bilgi Formu', 'Maslach Tükenmişlik Ölçeği' ve 'Kısa Semptom Envanteri' kullanılmıştır.

\section{Sosyodemografik Bilgi Formu}

$\mathrm{Bu}$ form literatür taranarak hazırlanmış olup, sosyodemografik bilgilerin sorgulandığı (katılımcıların yaşını, cinsiyetini, eğitimini vb.) 23 sorudan oluşmaktadır (Çoban-Kaynak, 2018; Demir-Saykıl1, 2019).

\section{Maslach Tükenmişlik Ölçeği}

Maslach ve Jackson (1996) tarafindan geliştirilmiş olup Maslach Tükenmişlik Ölçeği (MTÖ) yedi dereceli Likert tipi bir ölçek olup 3 alt ölçek ve 22 maddeden oluşmaktadır. Duygusal tükenme alt ölçeği 9, duyarsızlaşma alt ölçeği 5 ve kişisel başarı alt ölçeği de 8 maddeden oluşmaktadır. Ölçekteki tüm maddeler "1 hiçbir zaman" ve "7 her zaman" şeklinde puanlanmaktadır. Ölçek Ergin (1992) tarafindan Türkçe'ye çevrilmiş ve bazı değişiklikler yapılmıştır. Orijinal formunda 7 dereceli olan cevap seçenekleri " 0 hiçbir zaman", "4 her zaman" şeklinde beş dereceli olarak değiştirilmiştir. Puanlamada, her kişi için üç farklı tükenmişlik puanı hesaplanmaktadır. Duygusal tükenme ve duyarsızlaşma alt ölçeklerindeki yüksek puan ve kişisel başarı alt ölçeğindeki düşük puan tükenmişliğin yüksekliğini ortaya koymaktadır. Her üç alt ölçekten alınan puanların orta düzeyde olması orta düzeyde tükenmişliği gösterirken, düşük düzeyde tükenmişliği duygusal tükenme ve duyarsılaşma alt ölçeklerindeki düşük ve "kişisel başarı" alt ölçeğindeki yüksek puanlar göstermektedir. Ergin (1992) çalışmasında ölçeğin Cronbach Alpha katsayısını 0.83 olarak bulmuştur. Ölçeğin bu araştırma için Cronbach Alfa katsayısı 0.73 bulunmuştur.

\section{Kısa Semptom Envanteri}

Kısa Semptom Envanteri (KSE), çeşitli ruhsal semptomları değerlendirmek amaciyla Derogatis (1992) tarafindan geliştirilmiştir. Ölçek 53 madde ve 9 alt ölçekten oluşmaktadır. Ölçeğin puan aralığı 0-212 aralığındadır. Alt ölçek puanları her alt ölçeği oluşturan maddelere verilen puanlar toplanıp madde sayısına bölündüğünde elde edilir. Alt ölçek puanları 0 ile 4 arasındaki değerlerde olabilmektedir. Ölçekten alınan toplam puanın yüksekliği ruhsal semptomların sıklığının arttığ 1 şeklinde değerlendirilmektedir. Ölçeğin geçerlik ve güvenirlik çalışması Şahin ve Durak (2002) tarafından yapılmıştır. KSE'de 53 madde bulunmakta olup 9 alt ölçek, ek maddeler ve Rahatsızlık Ciddiyet İndeksi (RCI), Belirti Toplamı İndeksi (BTI) ve Semptom Rahatsızlık İndeksi (SRI) olmak üzere 3 global indeksten oluşmaktadır. KSE'nin asıl işlevselliğini gösteren değerlendirme Rahatsızlık Ciddiyeti İndeksi (RCI)'dir. Rahatsızlık ciddiyet indeksi puanının 1'in altında olması, semptomlarda normal dışı bir durumun varlığını göstermektedir. Şahin ve Durak (2002) çalışmalarında ölçeğin Cronbach Ala katsayısını 0.94 olarak bulmuştur. Ölçeğin bu araştırma için Cronbach Alfa katsayısı 0.99'dur.

\section{Verilerin Toplanması}

Veriler gerekli izinler alındıktan sonra Mayıs 2020'de T.C. Aile ve Sosyal Hizmetler Bakanlığı Erzurum İ Müdürlüğü' ne bağlı bakım kurumlarında çalışan bakım personelinden birebir toplanmıştır. Verileri toplamadan önce, bakım personeline araştırmanın içeriği hakkında bilgi verilmiştir. Çalışmaya dâhil edilen hiçbir katılımcı çalışmaya katılmaya zorlanmamış olup, verilerin toplanması sürecinde gizlilik ilkesine dikkat edilmiştir.

\section{Verilerin Değerlendirilmesi}

Araştırmadan elde edilen veriler, SPSS 20.0 paket programı ile veri girişi yapılarak istatistik analiz yapılmıştır. İstatistiksel analiz öncesi verilerin normal dağılıma sahip olup olmadığına bakılmış ve Maslach Tükenmişlik Ölçeği ve Kisa Semptom Envanteri puanlarının normal dağılmadığı saptanmıştır. Bundan dolayı parametrik olmayan istatiksel yöntemler kullanılmıştır. İki bağımsız örneklemden elde edilen puanların birbirlerinden anlamlı bir şekilde farklılık gösterip göstermediğini belirlemek için Mann-Whitney $\mathrm{U}$, ikiden fazla bağımsız örneklemden elde edilen puanların birbirlerinden anlamlı bir şekilde farklılık gösterip göstermediğini belirlemek için Kruskal-Wallis H ve değişkenler arasındaki ilişkinin tespiti için Spearman Korelasyon testi kullanılmıştır. Ortalama ve standart sapma değerlerinin tespiti için tanımlayıcı istatistik, demografik özellikleri sınıflandırmak için ise frekans testleri kullanılmıştır.

\section{Bulgular}

Araştırmanın bu bölümünde katılımcıların sosyodemografik özellikleri, kullanılan ölçekler ve alt ölçekler ve araştırma sorularına ilişkin bulgulara yer verilmiştir.

\section{Katılımcların Sosyo-Demografik Özellikleri}

Katılımcıların sosyo-demografik özelliklerine ilişkin bulgular Tablo 1'de verilmiştir. 
Tablo 1.

Katılımcıların Sosyo-demografik Özelliklerine İlişkin Bulgular (N=123)

\begin{tabular}{|c|c|c|}
\hline Sosyodemografik Özellikler & $\mathbf{N}$ & $\%$ \\
\hline \multicolumn{3}{|l|}{ Cinsiyet } \\
\hline Kadın & 83 & 67.5 \\
\hline Erkek & 40 & 32.5 \\
\hline \multicolumn{3}{|l|}{ Yaș } \\
\hline $21-30$ & 47 & 38.2 \\
\hline $31-40$ & 51 & 41.5 \\
\hline $41-50$ & 24 & 19.5 \\
\hline 51 ve üzeri & 1 & 0.8 \\
\hline \multicolumn{3}{|l|}{ Medeni durum } \\
\hline Evli & 80 & 65.0 \\
\hline Bekar & 43 & 35.0 \\
\hline \multicolumn{3}{|l|}{ Eğitim durumu } \\
\hline Lise & 76 & 61.8 \\
\hline Lisans & 47 & 38.2 \\
\hline \multicolumn{3}{|l|}{ Görev } \\
\hline Meslek Elemanı & 48 & 39.0 \\
\hline Bakım Personeli & 75 & 61.0 \\
\hline \multicolumn{3}{|l|}{ Aylık ücret } \\
\hline $2001-3000 \mathrm{TL}$ & 85 & 69.1 \\
\hline 3500 ve üstü TL & 38 & 30.9 \\
\hline \multicolumn{3}{|l|}{ Kurumda çalıșma șekli } \\
\hline Gündüz & 50 & 40.7 \\
\hline Vardiya & 73 & 39.3 \\
\hline \multicolumn{3}{|l|}{ Hizmet yılı } \\
\hline $1-5 \mathrm{y} 11$ & 84 & 68.3 \\
\hline $6-10$ y1l & 37 & 30.1 \\
\hline 11 yıl ve üzeri & 2 & 1.6 \\
\hline \multicolumn{3}{|l|}{ Kurumda çalıșma yılı } \\
\hline $1-3$ yil & 84 & 68.3 \\
\hline $4-6$ yil & 37 & 30.1 \\
\hline $7-9$ yil & 2 & 1.6 \\
\hline \multicolumn{3}{|l|}{ Çocuk Sahibi } \\
\hline Evet & 78 & 63.4 \\
\hline Hayır & 45 & 36.6 \\
\hline \multicolumn{3}{|l|}{ Mesleği kendi isteğiyle seçip seçmediği } \\
\hline Evet & 57 & 46.3 \\
\hline Hayır & 66 & 53.7 \\
\hline \multicolumn{3}{|l|}{ Mesleği seçmede en önemli etken } \\
\hline Sorumluluk taşıyabileceği için & 49 & 39.8 \\
\hline Kendisini bu mesleği yapabilecek donanımda gördüğü için & 23 & 18.7 \\
\hline Özel bir sebebi yok, sadece burada iș bulabildiği için & 51 & 41.5 \\
\hline \multicolumn{3}{|l|}{ İș doyumu } \\
\hline Evet & 36 & 29.3 \\
\hline Hayır & 87 & 70.7 \\
\hline \multicolumn{3}{|l|}{ İş devamsızlığı } \\
\hline Evet & 49 & 39.8 \\
\hline Hayır & 74 & 60.2 \\
\hline
\end{tabular}

Ölçek Puanlarının Değerlendirilmesi: Araştırmada kullanılmış olan Maslach Tükenmişlik Ölçeği ve Kısa
Semptom Envanteri alt ölçek değerleri Tablo 2'de gösterilmiştir.

\section{Tablo 2.}

Katılımcıların Maslach Tükenmişlik Ölçeği ve Kısa Semptom Envanteri’nden aldıkları Toplam Puan Ortalama ve Standart Sapma Değerleri

\begin{tabular}{|c|c|c|c|}
\hline & Minimum & Maximum & Ortanca \\
\hline \multicolumn{4}{|l|}{ Maslach Tükenmişlik Ölçeği } \\
\hline Duygusal tükenme & 0.00 & 4.00 & 23 \\
\hline Duyarsızlaşma & 0.00 & 4.00 & 8 \\
\hline Kişisel başarı & 0.00 & 4.00 & 14 \\
\hline \multicolumn{4}{|l|}{ Kisa Semptom Envanteri } \\
\hline Somatizasyon & 0.00 & 4.00 & 1.28 \\
\hline $\mathrm{OKB}$ & 0.00 & 4.00 & 1.66 \\
\hline Kişilerarası Duyarlılık & 0.00 & 4.00 & 1.00 \\
\hline Depresyon & 0.00 & 4.00 & 1.16 \\
\hline Anksiyete & 0.00 & 4.00 & 1.00 \\
\hline Hostilite & 0.00 & 4.00 & 0.80 \\
\hline
\end{tabular}


Fobik Anksiyete

Paranoid Düşünceler

Psikotizm

Ek Maddeler

Rahatsızlık Ciddiyet İndeksi

Belirti Toplamı Indeksi

Semptom Rahatsızlı İndeksi

$\begin{array}{lcc}0.00 & 4.00 & 0.60 \\ 0.00 & 4.00 & 1.40 \\ 0.00 & 4.00 & 1.00 \\ 0.00 & 4.00 & 1.25 \\ 0.00 & 4.00 & 1.17 \\ 0.00 & 53 & 36.00 \\ 0.00 & 4.00 & 1.89\end{array}$

duygusal tükenme ve duyarsızlaşma düzeylerinin orta, kişisel başarı düzeylerinin ise yüksek düzeyde olduğu görülmektedir.

Maslach Tükenmişlik Ölçeği'nin ölçeğinden elde edilen puanlar, tükenmişlik ölçeği puanlarının yorumlama tablosuna göre incelendiğinde (Tablo 3) katılımcıların

Tablo 3.

Tükenmişlik Ölçeği Puanlarının Yorumlama Tablosu

\begin{tabular}{lll}
\hline Alt Ölçek & Kategori & Kesme Puanı \\
\hline Duygusal Tükenme (0-54) & Yüksek & $\geq 27$ \\
& Orta & $19-26$ \\
Duyarsılaşma (0-30) & Düşük & $0-18$ \\
& Yüksek & $\geq 10$ \\
Kişisel Başarı (0-48) & Orta & $6-9$ \\
& Düşük & $0-5$ \\
& Yüksek & $0-33$ \\
& Orta & $34-39$ \\
\hline
\end{tabular}

Kısa Semptom Envanteri'nden elde edilen sonuçlar incelendiğinde katılımcılarda en fazla görülen ruhsal belirtiler arasında obsesif kompulsif bozukluk, paranoid düşünce, somatizasyon ve ek maddeler; en az görülen ruhsal belirtiler arasında ise fobik anksiyete, hostilite ve anksiyete ve kişilerarası duyarlılık olduğu görülmektedir.

Tablo 4.
Tükenmişlik ve Ruhsal Belirti Düzeyleri Arasındaki İlișkiye Yönelik Sonuçlar

Tükenmişlik Ölçeği ile Kısa Semptom Envanteri alt ölçek puanları arasında ilişki olup olmadığını anlamak amacıyla Spearman korelasyon analizi uygulanmıştır.

Tükenmişlik Ölçeği ile Kısa Semptom Envanteri Alt Ölçek Puanları Arasındaki İlişkiyle İlgili Korelasyon Değerleri

\begin{tabular}{|c|c|c|c|c|c|c|c|c|c|c|c|c|c|}
\hline & 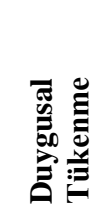 & 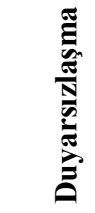 & 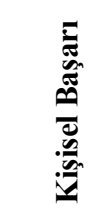 & 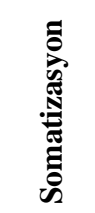 & قै & $\stackrel{2}{*}$ & 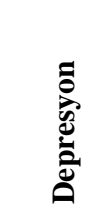 & 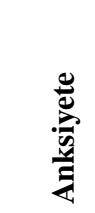 & 莺 & 卷 & ה & 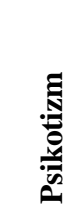 & $\sum_{\frac{y}{\pi}}^{\frac{0}{\sigma}}$ \\
\hline $\begin{array}{l}\text { Duygusal } \\
\text { Tükenme }\end{array}$ & & & & & & & & & & & & & \\
\hline Duyarsızlaşma & $.854^{* *}$ & & & & & & & & & & & & \\
\hline Kişisel Başarı & $-.348^{* *}$ & $-.528^{* *}$ & & & & & & & & & & & \\
\hline Somatizasyon & $.702^{* *}$ & $.745^{* *}$ & $-.423^{* *}$ & & & & & & & & & & \\
\hline OKB & $.668^{* *}$ & $.762^{* *}$ & $-.444^{* *}$ & $.916^{* *}$ & & & & & & & & & \\
\hline KAD & $.699^{* *}$ & $.773^{* *}$ & $-.424^{* *}$ & $.779^{* *}$ & $.771^{* *}$ & & & & & & & & \\
\hline Depresyon & $.788^{* *}$ & $.833^{* *}$ & $-.495^{* *}$ & $.899^{* *}$ & $.869^{* *}$ & $.893^{* *}$ & & & & & & & \\
\hline Anksiyete & $.662^{* *}$ & $.734^{* *}$ & $-.455^{* *}$ & $.814^{* *}$ & $.752^{* *}$ & $.834^{* *}$ & $.893^{* *}$ & & & & & & \\
\hline Hostilite & $.633^{* *}$ & $.747^{* *}$ & $-.449^{* *}$ & $.753^{* *}$ & $.716^{* *}$ & $.794^{* *}$ & $.848^{* *}$ & $.918^{* *}$ & & & & & \\
\hline Fobik Anksiyete & $.697^{* *}$ & $.821^{* *}$ & $-.489^{* *}$ & $.878^{* *}$ & $.869^{* *}$ & $.809^{* *}$ & $.894^{* *}$ & $.846^{* *}$ & $.857^{* *}$ & & & & \\
\hline Paranoid & $.707^{* *}$ & $.742^{* *}$ & $-.388^{* *}$ & $.866^{* *}$ & $.853^{* *}$ & $.896^{* *}$ & $.920^{* *}$ & $.806^{* *}$ & $.790^{* * *}$ & $.842^{* *}$ & & & \\
\hline Psikotizm & $.712^{* *}$ & $.14^{* *}$ & $-.491^{* *}$ & $.884^{* *}$ & $.926^{* *}$ & $.836^{* *}$ & $.933^{* *}$ & $.779^{* * *}$ & $.761^{* *}$ & $.889^{* *}$ & $.916^{* *}$ & & \\
\hline Ekmadde & $.734^{* *}$ & $.793^{* *}$ & $-.471^{* *}$ & $.844^{* *}$ & $.820^{* *}$ & $.857^{* *}$ & $.916^{* *}$ & $.897^{* *}$ & $.856^{* *}$ & $.884^{* *}$ & $.868^{* *}$ & $.867^{*}$ & \\
\hline
\end{tabular}

**. p< 0.01 anlamlılık seviyesinde ilișki anlamlı

Tablo 4 incelendiğinde, Tükenmişlik Ölçeğinin duygusal tükenme ve duyarsızlaşma alt ölçek puanları ile Kısa SemptomEnvanteri alt ölçek puanları arasında pozitif yönlü yüksek düzeyde bir ilişki bulunurken, Tükenmişlik Ölçeğinin kişisel başarı alt ölçek puanı ile Kısa Semptom Envanteri alt ölçek puanları arasında negatif yönlü yüksek düzeyde bir ilişki olduğu görülmektedir.

\section{Tartıșma}

Bu çalışmada T.C. Aile ve Sosyal Hizmetler Bakanlığı Erzurum İl Müdürlüğü'ne bağlı bakım kurumlarında görev yapmakta olan engelli ve yaşlı bakım personelinin tükenmişlik ve ruhsal belirti düzeyleri arasındaki ilişki değerlendirilmiştir.

Çalışma sonuçları incelendiğinde, katılımcıların duygusal tükenme ve duyarsızlaşma düzeylerinin orta, kișisel 
başarı düzeylerinin ise yüksek düzeyde olduğu görülmektedir. Korkut (2017), bakım elemanlarının tükenmişlik düzeyini incelediği çalışmada katılımcıların duygusal tükenme ve duyarsızlaşma düzeylerinin orta düzeyde olduğunu belirtmiştir. Papathanasiou (2015) sağlık bakım hizmeti verenlerle yaptığ çalı̧̧mada katılımcıların duygusal tükenme düzeylerinin orta düzeydeyken, duyarsızlaşma düzeylerinin yükseğe yakın olduğunu belirtmiştir. Çimen ve diğerleri (2012) özel bakımevi çalışanlarının tükenmişlik düzeylerine baktığı çalışmada, bakımevi personelinin duygusal tükenmişlik düzeylerinin yüksek, duyarsızlaşma düzeylerinin ise düşük olduğunu belirtmektedir. Rai (2010), kurum bakımı veren personelin tükenmişlik düzeyine baktığı çalı̧̧mada katılımcıların duygusal tükenme düzeylerinin orta, duyarsızlaşma düzeylerinin ise düşük olduğunu tespit etmiştir. Başol, Sağlam ve Çakır (2018) yaptıkları çalışmada engelli ve yaşlı bakım personelinin duygusal tükenme düzeylerinin düşük, duyarsızlaşma düzeylerinin ise çok düşük olduğunu tespit etmiştir. Bu çalışmanın sonuçları bakım personelinin tükenmişlik düzeylerine yönelik yapılan diğer çalışmaların bir kısmı ile benzerlik gösterirken diğer çalışmalarla göstermediği görülmektedir. Bunun nedeninin cinsiyet, yaş, medeni durum, eğitim durumu, gelir durumu, kişilik özellikleri, ihtiyaç ve beklentiler gibi bireysel faktörler ile iş yükü, aidiyet, yönetici ve diğer çalışanlarla ilişkiler, özerklik ve kararlara katılım gibi örgütsel ve kurumsal faktörlerin karmaşı etkileşiminin çalışanların tükenmişlik düzeyi üzerinde farklı etkilerinin olmasından kaynaklanabileceği düşünülebilir.

Kısa Semptom Envanterine yönelik sonuçlar incelendiğinde en yüksek puan ortalamasına sahip ruhsal belirtiler arasında obsesif kompulsif bozukluk, paranoid düşünce, somatizasyon ve ek maddeler; en düşük puan ortalaması olan ruhsal belirtiler ise fobik anksiyete, hostilite ve anksiyete ve kişilerarası duyarlılık olarak belirlenmiştir. Kaya (2016), bakım elemanlarının ruhsal durumlarını incelediği çalışmada en yüksek puan ortalamasina sahip ruhsal belirtiler arasında obsesif kompulsif bozukluk, paranoid düșünce, kișilerarası duyarlılık ve fobik anksiyete; en düşük puan ortalamasına olan ruhsal belirtiler ise somatizasyon, psikotizm, depresyon ve anksiyete olarak tespit etmiştir. Korkut (2017), yaptığı çalışmada depresyon ve hostilite ortalama puanlarının yüksek düzeyde, somatizasyon ve anksiyete puanlarının daha düşük düzeyde olduğunu belirtmiştir. Cevizci ve Müezzin (2019), sağlık çalıșanlarında psikolojik belirtilere baktığı çalışmada katılımcılarda hostilite ve depresyon puanlarının yüksek, somatizasyon ve anksiyete puanlarının düşük düzeyde olduğunu saptamıştır. Yeşil, Aker ve Sezgin (2009), hastalara bakım veren sağlık çalışanlarındaki ruhsal belirtileri saptamak amacıyla yaptıkları çalışmada, katılımcıların obsesif kompulsif bozukluk, paranoid düşünce ve depresyon puan ortalamalarının yüksek, fobik anksiyete, psikotizm, kişilerarası duyarlılık ve anksiyete puanlarının ise düşük düzeyde olduğunu tespit etmiştir. Bu çalışmada katılımcılarda en yüksek ve en düşük ruhsal belirtiler literatürdeki bazı çalışmalarla tutarlı iken diğer bazı çalışmalarla tutarlılık göstermemektedir. Bunun nedeni olarak ruhsal belirtilerin ortaya çıkmasında katkıda bulunabilecek çeşitli biyolojik (genetik, biyokimyasal, endokrin vb. nedenler), psikolojik (kişilik özellikleri, davranış, duygudurum vb.) ve sosyal (ekonomik, ailevi, iş yaşamında yaşanan sorunlar vb.) faktörlerin etkilesiminin her katılımcı üzerinde farklı etkilerinin olabileceği gösterilebilir.

Global indekslere bakıldığında Rahatsızlık Ciddiyeti İndeksi (RCI) katılımcıların yaşadıkları ruhsal semptomlardan duyduğu sıkıntının artmasına işaret etmektedir. Bu çalışmada katılımcıların RCİ madde puan ortancas1 1.17 olarak bulunmuştur. Belirti Toplamı İndeksi (BTI) ise katılımcının yaşadığı semptomların sayısını ortaya çıkarmaktadır. Çalışmada BTI puan ortancası 36 olarak bulunmuştur. Semptom Rahatsızlık İndeksi (SRI) ise katılımcının yaşadığı ortalama sıkıntı düzeyi hakkında bilgi sağlamaktadır. Çalışmada SRİ puan ortancası 1.89 olarak bulunmuștur. Özet olarak, bu çalışmada RCİ puanının yüksek, BTİ ve SRİ puanlarının ise orta düzeyde olduğu görülmektedir. Her ne kadar Kısa Semptom Envanteri puanlamasında RCI puanının 1'in üzerinde olması psikopatolojik bir durumun varlığını göstermekte olduğu belirtilmiş ise de bu çalışmada psikopatoloji tespitine yönelik herhangi bir psikiyatrik değerlendirme yapılmadığından psikopatoloji varlığı ya da yokluğu belirtilmesi yanlış olacaktır. Ancak çalışmanın sonuçlarının katılımııların yaşadıkları ruhsal belirtilerden duyduğu sıkıntının sorun oluşturacak düzeyde olduğunu gösterdiği söylenebilir. Yeşil, Aker ve Sezgin (2009), hastalara bakım veren sağlık çalışanlarındaki ruhsal belirtileri saptamak amacıyla yaptıkları çalışmada, katılımcıların ruhsal olarak zorlandıklarını saptamıştır. Kaya (2016) bakım ve rehabilitasyon merkezinde çalışan bakım elemanlarının ruhsal belirti düzeylerini incelediği çalışmada bakım personelinin çalışma şekli, meslekte yaşadıkları bazı sorunlar, stres düzeyleri ve daha önce ruhsal sorun yaşamış olmanın ruhsal belirti düzeylerini artırdığını belirtmiștir. Hendekçi ve Gök Uğur (2019) bakım elemanlarının yaşadığı sorunları değerlendirdiği çalışmada bakım personellerinin bakım sebebiyle bazı psikolojik sorunlar yaşadığını saptamıștır. Bir bașka çalışmada Danış ve Genç (2011) kurumsal bakım elemanlarının yaşadıkları sorunları ele aldıkları çalışmada katılımcıların stres, kaygı, yorgunluk, tükenmişlik ve bazı psikolojik sorunlar yaşadığını belirtmiştir. $\mathrm{Bu}$ araştırmanın bulgularının literatürde bakım elemanlarının psikolojik durumlarını inceleyen diğer araştırmalar ile benzerlik gösterdiği söylenebilir.

Araştırma sonucunda elde edilen diğer bir bulgu ise engelli ve yaşlı bakım personellerinin duygusal tükenmişlik ve duyarsılaşma ile ruhsal belirti düzeyleri arasındaki pozitif yönlü yüksek düzeyde bir ilișki bulunurken, kişisel başarı ile ruhsal belirti düzeyleri arasında negatif yönlü yüksek düzeyde bir ilişki olduğudur. Yeşil, Aker ve Sezgin (2019), çalışmalarında Kisa Semptom Envanteri'nin alt ölçekleriyle duygusal tükenme ve duyarsızlaşma arasında pozitif yönlü orta düzeyde bir ilişki olduğunu göstermiştir. Papathanasiou (2015), yaptığı çalışmada duygusal tükenmişlik ile depresyon ve anksiyete puan ortalamaları arasında pozitif yönlü, kişisel başarı puan ortalamaları arasında ise negatif yönlü bir ilişki saptamıştır. Greenglas, Burke ve Fiksenbaum (2001), yaptıkları çalışmada duygusal tükenmişlik ile somatizasyon arasında pozitif yönlü bir iliş̧ki saptamıştır. Fradelos ve diğerleri (2016), hemşirelerle yürüttüğü çalışmada tükenmişlik ile hostilite arasında pozitif yönlü yüksek düzeyde bir ilişki tespit etmiştir. Khorshidian ve diğerleri (2017), sağllk çalışanlarıyla yürüttükleri çalışmada tükenmişlik ile paranoid düşünceler arasında pozitif ve anlamlı düzeyde 
bir ilişki olduğunu belirtmiştir. Qiao ve diğerleri (2016), yaptıkları çalışmada tükenmişlik ile kişilerarası duyarlılık ve psikotizm arasında pozitif yönlü yüksek düzeyde bir ilişki olduğunu göstermiştir. Araştırmanın tükenmişlik ve ruhsal belirti düzeyleri arasındaki ilişkileri gösteren bulguları göz önünde bulundurulduğunda alanyazında bulunan çalışmalar ile benzer sonuçlar gösterdiği görülmektedir.

Sonuç olarak T.C. Aile ve Sosyal Hizmetler Bakanlığı Erzurum İl Müdürlüğü'ne bağlı bakım kurumlarında görev yapmakta olan engelli ve yaşlı bakım elemanlarının tükenmişlik düzeyleri ve ruhsal belirti düzeyleri arasındaki ilişkinin incelendiği bu çalışmada katılımcıların duygusal tükenme ve duyarsızlaşma düzeylerinin orta, kişisel başarı düzeylerinin ise yüksek düzeyde olduğu görülmektedir. Katılımcılarda sıklıkla görülen ruhsal belirtiler arasinda obsesif kompulsif bozukluk, paranoid düşünce ve somatizasyon olduğu tespit edilmiştir. Ayrıca bu çalışma engelli ve yaşlı bakım personelinin duygusal tükenmişlik ve duyarsızlaşma düzeyleri arttıkça ruhsal belirti düzeylerinin arttığını ve kişisel başarı düzeyleri arttıkça ruhsal belirti düzeylerinin azaldığını göstermektedir. Tükenmişlik düzeylerini ve buna bağlı ortaya çıkabilecek ruhsal belirtiler hakkında bu alanda daha fazla araştırma yapılması ve bakım kurumlarının duygusal tükenme ve duyarsızlaşmayı azaltmak ve ruhsal belirtileri en aza indirmek için bazı stratejiler geliştirmesi önem arz etmektedir. Nitekim bu araştırmanın sonuçları T.C. Aile ve Sosyal Hizmetler Bakanlığı Erzurum İl Müdürlüğü ile paylaşılmış ve sonucunda engelli ve yaşlı bakım elemanlarının tükenmişlik duygularını ve yaşadıkları bazı ruhsal belirtileri azaltmak, sorumluluklarını yerine getirmede yaşadıkları bilgi ve beceri eksikliğini gidermek, yaşadıkları korku, anksiyete, stres, öfke ve davranış sorunları ile baş etmelerini sağlamak ve bakım verdikleri bireylerle sağlıklı iletişim kurabilmeleri açısından hizmet içi eğitim düzenlenerek sosyal destek hizmeti sunulmuştur. Gelecek çalışmalarda araştırmacılar bakım elemanlarının tükenmişlik ve ruhsal belirti düzeylerini azaltmak için bakım elemanı olmanın duygusal ve varoluşsal yönlerini paylaşmaya ve öz bakım davranışları edindirmeye olanak sağlayacak çeşitli psikoterapötik yaklaşımlar ve teknikleri içeren grup çalışmaları uygulayarak bu çalışmaların bakım elemanları üzerindeki etkililiklerini inceleyebilir.

\section{Beyannameler}

\section{Etik Onay ve Katılma İzni}

Atatürk Üniversitesi tıp fakültesi klinik araştırmalar etik kurulu tarafindan 28.05.2020 tarihinde B.30.2.ATA.0.01.00/257 say1l izinle etik izin alınmıştır.

\section{Veri ve Materyallerin Mevcudiyeti}

Mevcut çalışma srrasında kullanılan ve / veya analiz edilen veri kümeleri, makul talep üzerine ilgili yazardan temin edilebilir.

\section{Çıkar Çatışması}

Yazarlar çıkar çatışması olmadığını beyan eder.

\section{Finansman}

Uygulanamaz.

\section{Yazar Katkıları}

NK verileri toplamıştır. MO verileri analiz etmiş, yorumlamış ve tartışmışıı. Tüm yazarlar makalenin son halini okumuş ve onaylamıştır.

\section{Yazarların Bilgileri}

Yazarlar ek bilgi vermeyi tercih etmedi.

\section{Teșekkür}

Uygulanamaz.

\section{Kaynaklar}

Aagestad, C., Tyssen, R., Sterud, T. (2016). Do work-related factors contribute to differences in doctor-certified sick leave? A prospective study comparing women in health and social occupations with women in the general working population. BMC Public Health, 16, 1-8. https://doi.org/10.1186/s12889016-2908-1

Ahola K. \& Hakanen J. (2007). Job strain, burnout, and depressive symptoms: A prospective study among dentists. Journal of Affective Disorders, 104, 103-110. https://doi.org/10.1016/j.jad.2007.03.004.

Aslan, E., Erbay, E. (2017). Ankara Aile ve Sosyal Politikalar İl Müdürlüğüne bağlı çocuk evlerinde çalışan bakım elemanları ve çocuk evi sorumlularının iş doyumu ve tükenmişlik düzeyleri. Türkiye Sosyal Araşttrmalar Dergisi, 2, 535-556.

Başol, O., Sağlam, Y., Çakır, N. N. (2018). Engelli ve yaşlı bakım personelinin tükenmişlik seviyeleri ile çalışma yaşamı kalitesi algısı ilişkisi. Toplum ve Sosyal Hizmet, 29(2), 71-97.

Bilgin, R., Emhan, A. ve Bez, Y. (2011). Sosyal hizmet kurumu çalışanlarında iş memnuniyeti, tükenmişlik ve depresyon: Diyarbakır ili alan araştırması. Elektronik Sosyal Bilimler Dergisi, 10(38), 210-228.

Borritz, M., Bültmann, U., Rugulies, R., Christensen, K.B., Villadsen, E., Kristensen, T. S. (2005). Psychosocial work characteristics as predictors for burnout: Findings from 3-Year follow up of the PUMA Study. Journal of Occupational and Environmental Medicine, 47(10), 1015-1025. https://doi.org/10.1097/01.jom.0000175155.50789.98
Cevizci, O., Müezzin E, E., (2019). Sağlık çalışanlarında psikolojik belirtilerin ve psikolojik dayanıklılığın incelenmesi. Kıbris Türk Psikiyatri ve Psikoloji Dergisi, 1(3): 166-72. https://doi.org/10.35365/ctjpp.19.1.21

Çimen, M., Şahin, B., Akbolat, M., Işsk, O. (2012). Özel bakım merkezinde çalıșan personelintükenmişlik ve iș doyum düzeylerine yönelik bir çalışma. Acıbadem Üniversitesi Sağllk Bilimleri Dergisi, 3(1), 21-31.

Çoban-Kaynak, R. (2018). Kurumsal bakım veren kuruluşlarda çalışan personelin mesleki doyum ve tükenmişlik düzeyi: Gümüșhane ili örneği. (Yayınlanmamıs Yüksek Lisans Tezi). Ankara Yıldırım Beyazıt Üniversitesi, Sağlık Bilimleri Enstitüsü, Ankara.

Danıs, M.Z., Genç, Y. (2011). Kurumsal bakım elemanlarının genel özellikleri ve yaşadıkları sorunlar. Yalova Sosyal Bilimler Dergisi, 2, 173-183.

Demir-Saykı11, M. (2019). Bakıcı personelin engelli bakımına yönelik tutumları, örgütsel destek, iş doyumu ve tükenmişlik algıları arasındaki ilişkiler. (Yayınlanmamış Yüksek Lisans Tezi). Bolu Abant İzzet Baysal Üniversitesi, Sosyal Bilimler Enstitüsü, Bolu.

Derogatis, L. R., \& Spencer, P. M. (1982). The Brief Symptom Inventory (BSI): Administration, and procedures manual-I. Baltimore, MD: Clinical Psychometric Research.

Ergin C. (1992, Eylül). Doktor ve hemşirelerde tükenmişlik ve Maslach Tükenmişlik Ölçeğinin uyarlanması. VVII. Ulusal 
Psikoloji Kongresi'nde sunulan bildiri. Hacettepe Üniversitesi, Ankara.

Fradelos, E.,Tsaras, K., Velentza, O., Vasiliadou, E., Aouant, N., Palla, P., Mitsi, D., Anastopoulou, K., Papathanasiou, I. (2016). Relation between burnout, mental health and aggression of nursing personnel. Journal of Disease and Global Health, 7, 156-163.

Freudenberger, H.J. (1974). Staff burnout. Journal of Social Issues, 30, 159-165.

Gray-Stanley, J. A., \& Muramatsu, N. (2011). Work stress, burnout, and social and personal resources among direct care workers. Research in Developmental Disabilities, 32(3), 10651074. https://doi.org/10.1016/j.ridd.2011.01.025

Greenglass, E.R., Burke, R. J., Fiksenbaum, L (2001). Workload and burnout in nurses. Journal of Community \& Applied Social Psychology, 11, 211-215. https://doi.org//10.1002/casp.614

Hendekçi, A., Gök Uğur, H. (2019). Bakım personellerinin yaşadığı sorunlar ve bakımdan etkilenme durumları. Journal of Academic Research in Nursing, 1-7. https://doi.org/10.5222/jaren.2019.66588

Innstrand S. T., Espnes G. A. \& Mykletun R. (2002) Job stress, burnout and job satisfaction: An intervention study for staff working with people with intellectual disabilities. Journal of Applied Research in Intellectual Disabilities, 17(2), 119126.Karasar, N. (2011). Bilimsel Araştırma Yöntemleri. Ankara: Nobel Yayınları.

Kaya, H. (2016). Bakım ve rehabilitasyon merkezinde çalıșan bakım elemanlarının ruhsal durumlarının incelenmesi. (Yayınlanmamış Yüksek Lisans Tezi). Yıldırım Beyazıt Üniversitesi, Sağlık Bilimleri Enstitüsü, Ankara.

Khorshidian, N., Hashemian, S. S., Meftagh, S. D. Najimi, A. (2017). Burnout among the employees of health and therapy entities: Investigating the role of early maladaptive schemas and mental disorder symptoms. Anatolian Journal of Psychiatry, 18(4), 323-329.

Kim, H., and Kao, D. (2014). A meta-analysis of turnover intention predictors among US child welfare workers. Child. Youth Serv. Rev., 47, 214-223. https://doi.org/10.1016/j.childyouth.2014.09.015

Kim, M. S., Kim, T. Lee, D., Yook, J. H., Hong, Y. C., Lee, S. Y., Yoon, J. H., \& Kang, M. Y. (2018). Mental disorders among workers in the healthcare industry: 2014 national health insurance data. Annals of Occupational and Environmental Medicine, 30, 31. https://doi.org/10.1186/s40557-018-0244-x

Korkut, Ayșe (2017). Engelli bakım ve rehabilitasyon merkezlerinde çalışan bakım elemanlarının bağlanma yönelimleri, stresle başa çıkma tarzları, sosyal destek algıları, psikolojik belirtiler ve bazı demografik özelliklerin tükenmişlik ile iliş̧isi. (Yayınlanmamış Yüksek Lisans Tezi). Fatih Sultan Mehmet Vakıf Üniversitesi, Sosyal Bilimler Enstitüsü, İstanbul.

Koutsimani, P. Montgomery, A., Georganta, K. (2019). The relationship between burnout, Depression, and anxiety: A systematic review and meta-analysis. Frontiers in Psychology, 10, 1-19. https://doi.org/10.3389/fpsyg.2019.00284
Maslach, C., and Leiter, M. P. (2016). Understanding the burnout experience: Recent research and its implications for psychiatry. World Psychiatry, 15, 103-111. https://doi.org/10.1002/wps.20311

Maslach, C., Jackson, S.E. (1996). Maslach Burnout Inventory. New York, NY: Psychologists Press, Consulting.

Maslach, C. ve Jackson, S. E. (1981). The measurement of experienced burnout. Journal of Occupational Behaviour, 2, 99113. https://doi.org/10.1002/job.4030020205

Mazurenko, O., Gupte, G., Shan, G. (2015). Analyzing U.S. nurse turnover: Are nurses leaving their jobs or the profession itself? Journal of Hospital Administration, 4(4), 48-56.

Milner, A., King, T. L., Kavanagh, A. (2019). The mental health impacts of health and human service work: Longitudinal evidence about differential exposure and susceptibility using 16 waves of cohort data. Preventive Medicine Reports, 14, 1-7. https://doi.org/10.1016/j.pmedr.2019.100826

MYK, (2016). Engelli ve yaşlı bakım elemanı ulusal mesleki standardı (Seviye 4), Ankara: MYK Yönetim Kurulu.

Oğuzberk, M., Aydın, A. (2008). Ruh sağlı̆̆ çalışanlarında tükenmişlik. Klinik Psikiyatri, 11, 167-179.

Papathanasiou, I. V. (2015). Work-related mental consequences: Implications of burnout on mental health status among health care providers. Acta Inform Med., 23(1), 22-28.

Qiao, Z., Chen, L., Chen, M. (2016). Prevalence and factors associated with occupational burnout among HIV/AIDS healthcare workers in China: A cross-sectional study. BMC Public Health, 16, 335. https://doi.org/10.1186/s12889-0162890-7

Rai, G.S. (2010). Burnout among long-term care staff. Administration in Social Work, 34(3), 225240. https://doi.org/10.1080/03643107.2010.480887

Ruotsalainen, J. H., Verbeek, J. H., Mariné, A., and Serra, C. (2015). Preventing occupational stress in healthcare workers. Cochr Library, 4, CD002892. https://doi.org/10.1002/14651858.CD002892.pub5

Sağlam, Y. (2017). Engelli ve yaşlı bakım personellerinin tükenmișliği, is yașamı kalitesi ve yașam doyumu ilișkileri üzerine bir araşırma. (Yayınlanmamıș Yüksek Lisans Tezi). Kırklareli Üniversitesi, Sosyal Bilimler Enstitüsü, Kırklareli.

Sahin, H.N., Durak, B.A., Ugurtas, S. (2002) Kisa Semptom Envanteri (KSE): Ergenler için kullanımının geçerlik, güvenilirlik ve faktör yapısı. Türk Psikiyatri Dergisi, 13(2), 125135.

Yeşil, A., Aker, A. T., Sezgin, U. (2009). Hemodiyaliz tedavisi gören hastalara bakım veren ekipte ruhsal belirtiler. Düşünen Adam, 22(1-4), 9-17.

Yunusoğlu, M. (2018). Mesleki stres ve tükenmişlik sendromunun depresyon üzerindeki etkisi: Van ilinde sağllk çalışanları üzerine bir uygulama. (Yayınlanmamış Yüksek Lisans Tezi). İstanbul Gelişim Üniversitesi, Sosyal Bilimler Enstitüsü, İstanbul. 